\title{
GENERAL PRINCIPLES OF PLANS OF CORPORATE REORGANIZATION
}

\author{
JoHn Gerdes †
}

So far, in the development of the principles of plans of corporate reorganization, we have reversed the natural order. We have dealt primarily with plans involving the reorganization of railroads and other corporations with highly complex capital structures. We have sought to evolve the principles of plans of reorganization in complicated situations and then apply them to the simpler situations. We have proceeded from the complex to the simple, instead of from the simple to the complex.

A critical analysis of the principles of plans of reorganization should be made. ${ }^{1}$ The efficacy of the principles should be tested in situations involving simple corporate structures in order that we may judge the results more clearly. The extent to which old principles have been modified by the statutory procedure provided by Chapter $\mathrm{X}^{2}$ of the Bankruptcy Act should be determined.

\section{Preliminary Considerations}

When a corporation, other than a railroad, insurance, banking, or municipal corporation, or a building and loan association, finds that it is unable to meet its obligations as they mature, or that its assets

$\dagger$ B. Litt., I907, Berea College; A. M., I9ro, LL. B., I9Io, LL. M., I9I I, J. D., IgI2, New York University; member of the firm of Gerdes \& Montgomery of the New York Bar; Chairman, Committee on Reorganizations of the American Bar Association (Commercial Law Section); Chairman, Committee on Bankruptcy and Reorganization of the Association of the Bar of the City of New York; Professor of the Law of Corporate Reorganizations at the New York University School of Law; Author of CoRPORATE REORganizations (3 vol. 1936) and numerous articles in legal periodicals.

I. Some of the articles written on the subject are: Dodd, The Los Angeles Lumber Products Company Case and Its Implications (1940) 53 HARV. L. REv. 7I3; Douglas and Frank, Landlord Claims in Reorganizations (1933) 42 Y ALE L. J. I003; Foster, Conflicting Ideals for Reorganization (1935) 44 YALE I. J. 923; Frank, Some Realistic Reflections on Some Aspects of Corporate Reorganization (1933) I9 VA. L. REv. 54I, 698; Friendly, Some Comments on the Corporate Reorganization Act (I934) $48 \mathrm{HARV}$. L. REv. 39, 74-8I; Gerdes, A Fair and Equitable Plan of Corporate Reorganization under Section $77 B$ of the Bankruptcy Act (1934) I2 N. Y. U. L. Q. REv. I; Graham, Fair Reorganization Plans under Chapter $X$ of the Chandler Act (1938) BRookLYN L. REV. I37; Payne, Fair and Equitable Plans of Corporate Reorganization (1933) 20 VA. L. REV. 37; Rosenberg, Reorganization-Yesterday, Today, Tomorrow (1938) 25 VA. L. REv. 129, 136; Spaeth and Winks, The Boyd Case and Section 77 (1938) 32 InI. I. REv. 769; Swanstrom, Stockholder' Participation in Reorganization (1939) 28 Geo. L. J. 336. See also FinLETter, The LAw of BankRUptCy Reorganization (1939) 416 et seq.; 2 Gerdes, CoRporate REORGaNizatTons (I936) \$§ I036-1106.

2. 52 Stat. 883-905, II U. S. C. A. \$§ 50I-676 (1940). The Bankruptcy Act contains sections numbered from I to 703 . Chapter $\mathrm{X}$ is contained in those sections numbered from IOI to 276. Citations to the Bankruptcy Act will hereafter refer only to section numbers. 
are less in value than the amount of its liabilities, relief may be had (I) by immediate liquidation in bankruptcy, ${ }^{3}$ (2) by liquidation over a period of years through the medium of a plan of reorganization (which should more accurately be termed a plan of liquidation), or (3) by reorganization under a plan of reorganization.

Selection of the relief sought should be determined by the best interests of the creditors and others who have interests in the corporation. Thus, liquidation should be resorted to if it will result in the realization of greater values for creditors and stockholders; reorganization is desirable if it will preserve for creditors and stockholders values which would be lost by liquidation. Reorganization preserves going-concern values which are usually lost by liquidation. It is therefore preferable unless the conditions of the industry, or the physical condition of the equipment, or some other factor, prevents effective reorganization, or unless full going-concern values may be preserved by a sale of the business for a full and adequate price. ${ }^{4}$

\section{A. Development of the Law}

Our law on the reorganization of corporations was, prior to the enactment of Sections $77^{5}$ and $77 \mathrm{~B}^{6}$ of the Bankruptcy Act in 1933 and I934, developed very largely in equity receiverships involving the reorganization of railroads. ${ }^{7}$ This is due to a definite public policy which demanded, and still demands, that the operation of railroads be continued for the benefit of the public, regardless of the best interests of their creditors and stockholders. Railroads are therefore not permitted to liquidate under the Bankruptcy Act. Even if liquidation were permitted, the nature of the assets of a railroad and the large values involved are such as to make it impractical except in rare and isolated instances.

The principles of reorganization have therefore been evolved in connection with the reorganization of corporations with large and unusually complicated capital structures-with numerous outstanding issues of bonds, secured by first, second, third and even fourth liens, as well as issues having different liens on different assets (first lien on some assets, second lien on other assets, etc.). Railroads with from ten to twenty issues of bonds, each with different rights and interests, are not uncommon. The difficulties in unraveling these com-

3. $\S 4$. 27 (1940).

4. Matter of Porto Rican American Tobacco Co., S. E. C., Corporate Reorg. ReI.

5. $\$ 77$.

6. $\$ 77 \mathrm{~B}$.

7. I GERDES, $o p$. cit. supra note I at $\$ \S$ I0-I2. 
plex structures, in accurately determining the values of the respective rights and interests of holders of the various issues of bonds and stock, and in equitably allotting interests in the reorganized corporation to such holders, were never completely overcome in the equity receivership. $^{8}$

At first the rights of security holders were left entirely to the voluntary agreement of the owners of the securities, acting through socalled protective committees. Dissenters were compelled to take their portion of such price as the reorganization committee, representing the security holders accepting the plan, might voluntarily bid for the assets of the corporation at the sale. Later, a small measure of protection to dissenters was given by the fixing by the court of a minimum upset price below which the assets could not be sold. ${ }^{9}$ Still later, under the so-called doctrine of the Boyd case, ${ }^{10}$ the courts began to examine plans to see whether their provisions wrongfully diverted to stockholders, interests in the reorganized corporation which should have been distributed to creditors. ${ }^{11}$

But the protection which the courts of equity could give to nonassenting creditors and stockholders prior to the enactment of the reorganization provisions of the Bankruptcy Act in 1933, 1934, and subsequent years, was limited. They had no adequate machinery to appraise the value of the various interests. In the main, the rights of creditors and stockholders depended on the bargaining powers of their committees, and the courts could only prevent glaring instances of unfairness. ${ }^{12}$

\section{B. The Objectives of a Reorganization}

The first objective of a reorganization should be the production of a sound economic unit-a corporation able to operate its business successfully and pay a reasonable return to those having interests in it.

8. Dodd, Reorganiation Through Bankruptcy: A Remedy for What? (I935) 48 HaRv. L. REv. I100, Iro0-IIIo; Friendly, note I supra at $4 \mathrm{I}-49$; Fuller, The Background and Techniques of Equity and Bankruptcy Railroad Reorganization (I940) 7 LAW \& Contemp. Prob. 377, 383.

9. For a general discussion of use of upset prices in corporate reorganizations, see 2 GERDES, op. cit. supra note I, \$§ I049-1066; Weiner, Conflicting Functions of the Upset Price (1927) 27 CoL. L. REv. 132.

ro. Northern Pacific Ry. v. Boyd, 228 U. S. 482 (I913). The application of this doctrine to corporate reorganizations is discussed in detail at p. 48 infra.

II. Dodd, note 8 sipra at IIor.

12. Two decisions of the Supreme Court at about the time of the enactment of Section $77 \mathrm{~B}$ indicated that plans effectuated through equity receiverships would be subject to closer scrutiny to determine their fairness. First National Bank v. Flershem, 290 U. S. 504 (I934) ; National Surety Co. v. Coriell, 289 U. S. 426 (I933).

The development of the principles of equity to be applied in the formulation of a fair plan of reorganization constitutes an interesting chapter in the history of our federal judicial system. I GERDES, op. cit. supra note $I$ at $\$$ Io. 
Unless this is accomplished, losses will continue, liquidation or another reorganization at a subsequent date will be necessary, and all losses sustained in the intervening period will diminish the amounts which could have been distributed to creditors and stockholders if liquidation or an effective reorganization had occurred in the first place. The statutes recognize this objective by requiring that the court must find that the plan is "feasible". ${ }^{18}$

The next important objective is an equitable distribution of interests in the reorganized corporation among the creditors and stockholders of the old corporation. This is also one of the prime purposes of a liquidation in bankruptcy, ${ }^{14}$ the difference being that in bankruptcy the assets of the corporation are converted into cash, which is distributed, while in reorganization the assets are retained, in whole or in part, by the corporation, and interests in such assets are distributed in the form of new or revised interests (obligations assumed or shares of stock) in the reorganized corporation.

Most reorganizations also involve liquidation in part. Excess inventories may be reduced, and unprofitable plants or other assets sold. If sufficient cash is realized, creditors may receive cash for part of their claims, and obligations or stock of the corporation for the balance.

A recognition that reorganization as well as liquidation is a procedure to divide the assets of the corporation among those entitled to them, is fundamental. Without this recognition there can be no adequate discussion of the principles of a plan of reorganization.

\section{General Principles}

When people extend credit to or purchase the securities of a corporation they bargain and pay for certain rights and privileges. An unsecured creditor bargains for payment of a specified amount on a specified date, with or without interest, and, if with interest, at a rate expressly agreed upon or at a rate which by the law of the jurisdiction in which the transaction occurs is made a part of his contract. Under the common law, upon a default in the payment of either principal or interest, each creditor may procure a judgment fixing the amount due to him from the debtor, and, by appropriate legal procedure, may then seize and sell such assets of the debtor as are available and apply the proceeds to the satisfaction of his judgment. A "race of diligence" results, and unless the assets of the debtor are suff-

13. $\$ \S 174,221$ (2).

I4. Maynard v. Elliott, 283 U. S. 273, 277 (I93I); GlenN, Ligumatron (1935) \$3; Swaine, Reorganization-An Amendment to the Bankruptcy Act (1933) ig VA. L. REV. 3I7, 322-323. 
cient upon quick liquidation to pay all creditors in full, some creditors will be paid in full, while others will receive nothing, or only a part of their claims. The indiscriminate seizure and quick sale of assets will destroy the business of the debtor and most of the value of the assets will be sacrificed.

All of our bankruptcy statutes, since the enactment of the first English Bankruptcy Act in I542, have sought to prevent the commonlaw race of diligence among creditors when its result will be an inequitable distribution of assets among creditors having equal rights. Such statutes have provided for a sale of all the assets of the debtor and a pro rata distribution of the proceeds among unsecured creditors when the debtor is insolvent. And, as under the common law, ${ }^{16}$ creditors are paid in full before there is any distribution to stockholders.

In equity receiverships also the courts sell all of the assets of the debtor and distribute the proceeds pro rata among the unsecured creditors, nothing going to stockholders until all creditors have been paid in full. ${ }^{16}$

Bankruptcy and equity receivership proceedings successfully prevented discrimination among creditors having equal rights when the assets of the debtor were insufficient to enable all creditors to be paid in full, but they provided no substitute for the common-law requirement that the assets of the debtor be liquidated by an immediate sale. The problem of preventing the sacrifice of going-concern values still remained.

The Bankruptcy Act of 1898 sought to meet this problem by the provisions of Section $12,{ }^{17}$ dealing with "compositions". Under this Section a bankrupt, in a bankruptcy proceeding, could make an offer to all his unsecured creditors for the satisfaction of their claims by payment of part of such claims. ${ }^{18}$ If the holders of a majority in number and amount of claims accepted the offer, and if the court found that it was for the best interests of the creditors that the offer be accepted, all creditors were bound to accept the payments provided in the composition agreement in full satisfaction of their claims. The statute

15. At the common law, stockholders have no right to receive any of the assets of the corporation except in payment of dividends which have been declared. Dividends may be declared only out of the surplus remaining after sufficient assets are set aside to cover the capital of the corporation and all the claims of creditors. Upon dissolution, all classes of creditors are paid in full in the order of their priority before any of the assets are divided among the stockholders.

16. Kansas City Terminal Ry. v. Central Union Trust Co. of New York, 27I U. S. 445 (I926) ; Northern Pacific Ry. v. Boyd, 228 U. S. 482 (I9r3).

17. 30 STAт. 549 (I898), II U. S. C. A. \$ 30 (I934).

18. While compositions involving the giving of notes as well as cash have been confirmed, it has never been satisfactorily established that creditors could be compelled to accept other securities under a composition agreement. In re Kornbluth, $65 \mathrm{~F}$. (2d) 400 (C. C. A. 2d, I933); In re Isidor Klein, Inc., 22 F. (2d) 906 (C. C. A. 2d, 1927). See Glem, Liqumation (1935) \$380. 
was construed as authorizing courts to approve compositions only when the offer gave to creditors at least the substantial equivalent of what they would receive if the bankruptcy were continued. ${ }^{18}$

The theory of the composition was simple: If a majority of the creditors wished to avoid the risks of liquidation in bankruptcy, and if all creditors would receive at least as much on their claims under the composition agreement as they would receive if the bankruptcy proceeding continued to consummation, a sacrifice of the going-concern value of the assets of the bankrupt by quick sale was unnecessary as well as inequitable.

Nothing was taken from dissenting creditors by a composition agreement except the right arbitrarily to insist on a sale of assets, which would result in no benefit to them. All that composition did was to deprive individual creditors having rights in property commonly owned by all the creditors and stockholders (if the bankrupt was a corporation) from insisting upon a particular remedy-an immediate sale of such property-against the wishes and interests of a majority of those having the common interest. The sale would bring injury upon the others, without any benefit to the person insisting thereon. The composition agreement was a new protection given to both creditors and stockholders in that both were now assured that compulsory liquidation, with its resulting loss in values, would not be necessary simply because a minority, however small, might arbitrarily insist upon it. There is no moral or equitable principle which gives to a minority a vested right to sacrifice the interests of all by insistence upon a remedy which can only result in a loss to all. ${ }^{20}$

The procedure in Section $77 \mathrm{~B}$ of the Bankruptcy Act, enacted in 1934, definitely aimed at this preservation and distribution of goingconcern values instead of liquidation values among those having claims against or interests in the corporation. If two-thirds of each class of creditors and a majority of each class of stockholders having an equity in the assets accepted the plan of reorganization, and the court found that the plan fairly and equitably distributed interests in the corporation to those entitled to such interests, dissenting minorities were compelled to take the securities or other property allotted to them under the plan in satisfaction of their claims or interests. ${ }^{21}$ Creditors or stockholders of a non-accepting class could not be compelled to take new securities for their interests, but dissenting creditors or stockholders of

I9. In re Reiman, 20 Fed. Cas. 490,496, No. II,673 (S. D. N. Y. I874), aff'd, 20 Fed. Cas. 500, No. II,675 (C. C. S. D. N. Y. 1875). See United States ex rel. Adler v. Hammond, In4 Fed. 862, 868 (C. C. A. 6th, 1900).

20. See Matter of People, 264 N. Y. $69,92,190$ N. E. 153, r6r (1934); Head v. Amoskeag Manufacturing Co., II3 U. S. 9, 2I (I885).

21. $\$ 77 \mathrm{~B}(\mathrm{e})(\mathrm{I}),(\mathrm{f})(\mathrm{I}),(\mathrm{g})$. 
an accepting class were compelled to take the securities allotted to them under the plan.

The provisions of the present Chapter X of the Bankruptcy Act are similar in the foregoing respects to the provisions of the superseded Section $77 \mathrm{~B}$, except that classes of creditors and stockholders, if the court finds the plan fair and equitable, are bound if the plan receives the assent of two-thirds or a majority, respectively, of those in their classes who have filed individual proofs of claim or interest, instead of these proportions of each entire class. ${ }^{22}$

\section{A. Recognition of Priorities}

In equity receivership and composition, as well as in dissolution, bankruptcy and the enforcement of the common law rights of creditors, it is clear that we are dealing with liquidation procedures under which, in the absence of an express agreement waiving such right, each creditor and stockholder is entitled to such amount in cash (or notes of the bankrupt, in the case of a composition) as represents the full liquidation value of his claim, giving effect to all of his priorities and other rights. All secured creditors and creditors having priorities must be paid in full before creditors without priority or security may receive anything; unsecured creditors must be paid in full before any payment may be made to stockholders; and preferred stockholders are entitled to payment to the full extent of their preferences before payment may be made to common stockholders. In each of these procedures the minimum amount which a creditor or stockholder can be compelled to take was his equity in the debtor, calculated on the basis of liquidation values. In composition, he might have secured a larger amount if the composition agreement so provided. In bankruptcy or equity receivership, he may secure the going-concern value of his interest and waive his right to payment in cash of its liquidation value, by voluntary acceptance of a plan of reorganization. But in no instance may he be deprived, without his consent, of his full common-law right to have the liquidation value of the debtor's assets appropriated to the satisfaction of his entire claim before any part of such value is paid to holders of junior claims and interests.

In the case of enforcement of common-law rights, in bankruptcy, and in the equity receivership, this liquidation value is fixed by the amount of the net proceeds realized from the sale. In composition, the liquidation value of the interests of the creditors is determined by the court, which, before approving the composition agreement, is compelled to find that the composition gives to creditors the full equivalent 
of what they would receive if liquidation in bankruptcy were completed.

As already pointed out, the reorganization procedures provided in Section $77 \mathrm{~B}$ and Chapter $\mathrm{X}$ do not seek to divide the proceeds of $\mathrm{a}$ liquidation of the assets of the debtor. Rather they preserve from destruction going-concern values which are thus made available for the payment of claims against and interests in the debtor.

Nor do the provisions in Section $77 \mathrm{~B}$ or Chapter $\mathrm{X}$ show any intent to change the contract and common-law priorities of creditors and stockholders in this process of distribution. In fact, the contrary intent is clearly expressed: the assents of stockholders are not necessary, and the plan may wipe out their interests without making provision for them, if the debtor is insolvent, ${ }^{23} i$. e. if the assets of the debtor are not sufficient to cover the claims of its creditors in full ; ${ }^{24}$ and provision for non-assenting classes of creditors need only be made to the extent of the value of their interests in the property of the debtor.

The preservation of going-concern values merely enlarges the pot available for distribution; it does not change the relative interests or equities of creditors and stockholders in the pot. Creditors and stockholders both benefit from this preservation of going-concern values. Where the corporation is solvent on the basis of liquidation values, the entire benefit inures to stockholders; where the corporation is insolvent even on the basis of going-concern values, the entire benefit goes to creditors; in all other cases both creditors and stockholders reap the benefits.

\section{B. Absolute Priority Theory}

When the assets of the debtor are taken by the court in the reorganization proceeding, the bargained-for rights and priorities (as to liens on property as security, rights of priority upon the distribution of assets, rates of interest, date of maturity, etc.) of the creditors and stockholders become effective. Full effect should be given to these rights and priorities in valuing the equity of each class of creditors and stockholders in the assets of the debtor. Interests in the reorganized corporation should not be given to classes of creditors and stockholders if they have no equity. This is the "absolute priority theory". ${ }^{25}$

23. $\S 77 \mathrm{~B}(\mathrm{~b})(4),(\mathrm{e})(\mathrm{I}) ; \S \S 179,216(8)$.

24. § I (19).

25. The Securities and Exchange Commission has strongly urged the adoption of the absolute priority theory. See address by Jerome N. Frank, Chairman, Securities and Exchange. Commission, delivered before Association of the Bar of the City of New York, March 27, I940; and address by J. Anthony Panuch, Special Counsel, Reorganization Division, Securities and Exchange Commission, delivered before New York County Lawyers Ass'n, Nov. 21, 1939, Wall Street Journal, Nov. 22, 1939, p. 10, col. 5. See also reports of Securities and Exchange Commission on plans in specific reorganization. 
Going-concern values may be created or lost by the changes or readjustments provided for in the plan. In either event, the interests available for distribution to the old creditors and stockholders are interests in the debtor as reorganized under the plan. These interests must therefore be evaluated to determine whether creditors and stockholders have been accorded their respective legal rights and priorities. The fairness of the plan must be tested by the value-although not necessarily the market price ${ }^{28}$ - of the securities or other consideration given to creditors and stockholders under the plan. If classes of creditors and stockholders having priority receive value fully equivalent to the legal amount of their claims or interests, subsequent classes may be awarded an interest under the plan. The grant of an interest to a subordinate class when a prior class has not received full value, renders the plan unfair and inequitable. ${ }^{27}$

If the secured creditor receives the full value of his bargained-for rights, and the common stockholder receives no more than he is entitled to, neither may justly complain if payment is made to each in securities of the same class. ${ }^{28}$ If, on the other hand, the secured creditor is deprived of the full value of his interest, and the stockholder receives an interest in the reorganized debtor which should have been given to the secured creditor, then the plan is unfair and inequitable, even if the face amount of the new securities given to the secured creditor is equal to the full amount of his claim and such new securities are given full priority in the distribution of assets on dissolution over the new securities given to common stockholders

To illustrate: If the going-concern value of the reorganized corporation is $\$ 700,000$, and the debtor has $\$ 1,000,000$ of secured bonds and $\$ 500,000$ par value of common stock outstanding, and there are no unsecured creditors or preferred stockholders, a plan which gives $\$ 1,000,000$ par value of new preferred stock to the holders of the secured bonds and gives all the new common stock (regardless of the par value of such shares) to the old stockholders, is unfair. Under these facts, the bondholders are entitled to all of the interests in the reorganized debtor. ${ }^{20}$

Again: If the going-concern value in the above illustration were $\$ 1,200,000$ instead of $\$ 700,000$, a plan giving $\$ 1,000,000$ of new com-

26. See Dodd, note 8 supra at Ir33-1134; Friendly and Tondel, The Relative Treatment of Securities in Railroad Reorganizations under Section 77 (1940) 7 LAW AND CONTEMr. Prob. 420, 423.

27. Case v. Los Angeles Lumber Products Co., 308 U. S. I06 (I939).

28. Friendly and Tondel, note 25 supra at 424 .

29. In addition to the plan being unfair, the security holders might be subjected to liabilities under state law regulating the issuance of stock for a consideration less than its stated value. See Brockett v. Winkle Terra Cotta Co., 8I F. (2d) 949 (C. C. A. 8th, I936). 
mon stock to the secured bondholders and $\$ 200,000$ of new common stock to the old stockholders would normally be fair. Under the same facts, a plan giving $\$ I, 000,000$ par of preferred stock to the old secured bondholders and $\$ 200,000$ par of common stock to the old common stockholders, is not necessarily fair. It may be fair, or otherwise, depending upon the value of the control of the corporation vested in the common stock and its unlimited right to dividends after payment of dividends on the preferred stock, as compared with the value of the preferences given to the preferred stock.

In this regard, it is important to remember that stockholders are entitled to the value of their equities just as much as secured and unsecured creditors. If, in the last of the foregoing illustrations, the secured bondholders are given $\$ 800,000$ par value of preferred stock and the entire issue of $\$ 200,000$ par value of common stock, while the old common stockholders receive options to purchase $\$ 200,000$ par value of common stock for $\$ 100,000$, the plan will be unfair to the old common stockholders. It is not fair to compel stockholders to pay $\$ 100,000$ in cash as a condition to their right to secure the value of their equity.

This does not mean that a plan may never give creditors or stockholders rights or options to purchase shares of stock. If the equities of such creditors or stockholders are small and uncertain, a plan may give such rights or options if their value is approximately equal to the value of the equities. Even if such creditors or stockholders have no equities, a right to subscribe for shares may be given if the amount to be paid on the exercise of the right is approximately the value of the shares subscribed for, and if the right must be exercised immediately. A right or option to purchase in the future-regardless of the price specified-gives an interest in the corporation which may be justified only by the value of the present equity of the creditors or stockholders receiving the right or option or by the new cash or other consideration paid by them.

\section{The Boyd Case}

The foregoing principles are not the only ones to be applied in the determination of interests to be given under a plan. The so-called doctrine of the Boyd ${ }^{30}$ case, based upon the law of fraudulent conveyances, is also applicable. ${ }^{31}$ Under this doctrine, it is held that a debtor may not withhold any of his property from seizure for the satisfaction

30. Northern Pacific Ry. v. Boyd, 228 U. S. 482 (19r3).

3I. See 2 Gerdes, op. cit. supra note 1, §\$ I083-I085; GlenN, Fraudulent ConVEYANCES AND PREFERENCES (1940) \$\$ 224, 225. 
of the claims of his creditors, regardless of whether such property has been acquired by purchase or gift. Where the assets of a debtor are divided among its creditors, if any property of the debtor is given to, or is available for the satisfaction of the clain of, a specific creditor who surrenders his right and returns the property to the debtor, such property immediately becomes available for the payment of other creditors whose claims have not been paid in full. The fact that the property has been donated by another creditor does not put it beyond the reach of creditors, and any device or plan which seeks to prevent them from seizing such property for the satisfaction of their claims, is fraudulent as against them.

In the Boyd case, secured creditors who were entitled to all the assets of the corporation voluntarily gave an interest in such assets to the stockholders although unsecured creditors received nothing. The court held that the giving of an interest in the property to the stockholders was equivalent to giving it to the debtor corporation, and that the value of the interest given to stockholders should be made available for the payment of such claims of the corporation as were still unsatisfied. For the purpose of doing justice the veil of the corporate entity was pierced and the stockholders were treated as if they were the corporation.

The application of the Boyd doctrine to a plan under Chapter X may be illustrated as follows: The corporation has as its sole asset a hotel with a going-concern value of $\$ 100,000$. Bonds in the amount of $\$ 200,000$ secured by a first mortgage on the property, are outstanding; there is a bond for $\$ 50,000$ secured by a second mortgage; and there are unsecured creditors and common stockholders.

Under these facts, no plan would be fair unless it gives all interests in the reorganized corporation to the bondholders. But, suppose the bonds and mortgage were owned by a single individual, $X$, who agrees, with full knowledge of his rights, to a plan under which he gets a new bond for $\$ 75,000$, secured by a first mortgage, and the stockholders retain their stock; the holder of the second mortgage and the unsecured creditors get nothing. Under the Boyd doctrine the value of the interest given to stockholders can be reached by the holder of the second mortgage and the unsecured creditors for the satisfaction of their claims.

\section{Statutory Standards}

Section 77 B set up a new statutory standard for plans. Under it a judge could not confirm a plan unless he was satisfied that "it is fair and equitable and does not discriminate in favor of any class of 
creditors or stockholders". ${ }^{2}$ Although it is commonly believed that this language should be construed to prevent recognition of a plan providing for distribution to any subordinate class of creditors or stockholders unless all prior classes have had their claims recognized in full, even if there has been no violation of the Boyd doctrine, ${ }^{33}$ the United States Supreme Court has never passed upon the question.

Thus, under the facts of the last illustration, assume that $X$ has agreed to a plan which gives him a new bond for $\$ 75,000$ secured by a first mortgage, gives all of the common stock to unsecured creditors who hold tort claims against the corporation, and gives nothing to the holder of the second mortgage or to the old stockholders. Such a plan would not violate the contractual or common-law rights of the second mortgagee; nor would it violate the Boyd doctrine, since it does not divert assets to stockholders. ${ }^{34}$ The plan should nevertheless be held to be a violation of the statute.

The facts permit of two different inferences: (I) that the first mortgagee intended a direct gift to the tort claimants; or (2) that the first mortgagee merely consented to a reduction in his claim. If the first mortgagee intends a gift, there seems to be no principle in law or in equity which would require us to make available to the second mortgagee the interest in the corporation which belongs to the first mortgagee and which he voluntarily transfers to other creditors of the corporation.

On the other hand, if the first mortgagee merely intends to accept a reduction in his claim, the estate of the debtor becomes the beneficiary, and the assets freed by the reduction in claim should be made available for the satisfaction of the claims of other creditors. A further question then arises: As a reduction in the amount of the claim of the first mortgage automatically reduces the first lien on the property, does such reduction inure solely to the benefit of the second mortgagee who has a first claim against the property after the lien of the first mortgage has been satisfied? Or should we consider that the lien of the second mortgage had no value prior to the consummation of the plan and that the second mortgagee must therefore be treated as an unsecured creditor for all purposes in the proceeding? A fair and equitable plan under the circumstances would provide that the $\$ 25,000$ interest surrendered by the first mortgagee be distributed

32. $\$ 77 \mathrm{~B}(\mathrm{f})(\mathrm{I})$.

33. See Frank, Some Realistic Reflections on Some Aspects of Corporate Reorganization (1933) Ig VA. L. REV. 54I, 55I-553; Swaine, Reorganization of Corporations, Certain Developments of the Last Decade (1927) VIII SOME LEgal Phases or Corporate Financing Reorganization and Rggulation 1926-1930, 131, 142.

34. New York Trust Co. v. Continental \& Com. Trust and Sav. Bank, 26 F. (2d) 872 (C. C. A. 8 th, 1928). 
among all the unsecured creditors, treating the second mortgagee as part of this group, because the second mortgage lien was valueless.

The first mortgagee could have insisted on a plan under which he would be entitled to all of the property of the corporation. $\mathrm{He}$ could later have donated an interest to anybody (provided the alleged donation be not made under the terms of an agreement, made prior to the confirmation of the plan, which was intended to influence action in the proceeding). The plan should, however, not be made the vehicle for such a donation. Each class of creditors should act for its own interests in the plan, and any reduction in claim accepted unanimously by any class should be considered as being made for the benefit of the debtor's estate. This avoids troublesome questions of intent and also discourages agreements to buy off obstreperous and subordinate classes at the expense of other classes.

If, in the foregoing situation, the first mortgage had covered a number of bonds and all holders of the bonds had voluntarily given up part of their interests, similar principles would be involved. But, if even one holder of the bonds had objected, the plan must be held to be unfair. No minority, no matter how small, may be deprived of its right to payment in full before any interest is given to a subordinate class. ${ }^{35}$

Chapter $\mathrm{X}$ retains the requirement of Section $77 \mathrm{~B}$ that the plan must be "fair and equitable" 86 but eliminates the requirement that it must "not discriminate in favor of any class of creditors". But no change in the law was intended by this change in language. ${ }^{37}$

The plan in the Los Angeles Lumber Co. ${ }^{38}$ case violated not only the common-law and contractual rights of the bondholders and the doctrine of the Boyd case, but also the statutory standards of Section $77 \mathrm{~B}$ and Chapter $\mathrm{X}$. Bondholders were not allotted the full equivalent of their interest in the debtor; and stockholders were given an interest in the debtor which should have been made available to its creditors.

Chapter $\mathrm{X}$ provides further that no plan may be approved by the court unless the interests of non-accepting classes of creditors and stockholders are protected by the retention of their interests in such property, or by payment in cash of their portion of the proceeds of a sale of the property at not less than an upset price fixed by the court, or by payment in cash of the appraised value of their interests. ${ }^{39}$

35. Case v. Los Angeles Lumber Products Co., 308 U. S. 106 (I939).

36. §22r (2).

37. See Gerdes, Corporate Reorganizations: Changes Effected by Chapter $X$ of the Bankruptcy Act (1938) 52 HARv. L. REV. I, 34; SEN. REP. No. I916, 75th Cong., 3d Sess. (1938) pp. 35-36.

38. Case v. Los Angeles Lumber Products Co., 308 U. S. I06 (I939).

39. \& 216 (7) (8). Identical provisions were contained in Section $77 B$ (b) (4) (5). 
Under these provisions, a class which refuses to cooperate in preserving the going-concern value of the assets of the corporation may not insist on getting cash in full for its proportion of the going-concern values, preserved in spite of its failure to cooperate. To permit such recovery would result in grave injustice to the other classes of creditors and stockholders, who will be compelled not only to accept securities for their interests but also, in all probability, to raise the cash necessary to pay the non-accepting class. Liquidation must inevitably follow if all classes refuse to accept payment in securities. Equitably, therefore, non-accepting classes should be paid in cash the liquidation, ${ }^{40}$ and not the going-concern, value of their claims and interests. It is not sufficient however to offer to any class of creditors merely the liquidation value of their interest in the debtor. They are entitled to a fair offer of the going-concern value of their claims in securities. Only if this offer is not accepted may they be compelled to take, in cash, the liquidation value of their interests. As used in Subsections (7) and (8) of Section 216 of Chapter $X$, the value of their claims against or equity in the property of the debtor must be construed to be such property without the increment in value due to the preservation of the business as a going concern.

To illustrate: Suppose the liquidation value of the property of the debtor is $\$ 600,000$, and its going-concern value is $\$ 1,000,000$; the secured indebtedness is $\$ 500,000$; unsecured claims amount to $\$ 300$,ooo; and there are outstanding shares of common stock. The liquidation value of the claims of unsecured creditors therefore is \$100,000 and the interests of stockholders have no liquidation value. The going-concern value of the claims of unsecured creditors is $\$ 300,000$ and the going-concern value of the interests of stockholders is $\$ 200,000$.

Under these facts, any reorganization under which the creditors are compelled to put up $\$ 200,000$ in cash to pay the stockholders who have not accepted the plan, would not be fair or equitable; nor would it be fair or equitable if the unsecured creditors are deprived of their additional $\$ 200,000$ of going-concern value by a compulsory liquidation because the stockholders have refused to accept the plan. Since the stockholders would get nothing by liquidation, and since they are unwilling to take the securities which fully and fairly represent the

40. "Liquidation" value does not mean scrap value; it may be defined as the higher of the two amounts which may reasonably be expected if the property is sold over a reasonable period of time by a person who actively seeks a buyer, and if the property is sold in the aggregate or in separate lots. See First National Bank v. Flershem, 290 U. S. 504, 526 (I934), where the court, in an equity receivership, said that the dissenting creditor was entitled to "that sum in cash which it would have received if the property had been sold at a proper price". 
going-concern value of their interests in the debtor, they should receive nothing in cash.

Suppose the situation were reversed in the foregoing illustration: The unsecured creditors refuse to accept a plan which makes adequate provision for the issuance to them of securities fully representing their going-concern interest of $\$ 300,000$. The plan has been accepted by the secured creditors and the stockholders. Under the facts as thus altered, the unsecured non-assenting creditors should not receive more than $\$ 100,000$ in cash if the plan provides for an appraisal of their claims against the property. If the plan provides for a sale of the property, subject to the lien of the first mortgage, at not less than an upset price, then the upset price should be fixed at $\$ 100,000$.

On first impression, this result seems inequitable, and unduly favorable to the stockholders. It should be remembered, however, that the unsecured creditors have rejected a fair offer of the going-concern value of their claims.

The Boyd doctrine is not violated in the last variation of the illustration because: (I) the fair offer required by the Boyd case was made to the unsecured creditors and rejected by them; ${ }^{41}$ (2) the cash required to pay the $\$ 100,000$ to the unsecured creditors in practically all cases would be paid by the stockholders, and as such sum, by hypothesis, is the reasonable liquidation value of the assets above the liens of the secured creditors, it is sufficient new consideration to support the interest given to the old stockholders; ${ }^{42}$ and (3) since Chapter $\mathrm{X}$ requires that dissenting classes be paid only this amount, the Boyd doctrine (even if this were a violation of it) must be deemed to have been modified to this extent by the statute.

\section{Determination of Values}

There is no convenient rule of thumb for determining the goingconcern value of the reorganized debtor, or of the securities allotted under the plan. While there is fairly general agreement that the going-concern value of a business depends primarily upon its prospective profits and that a capitalization of such profits is the best means of fixing this value, ${ }^{43}$ no precise formula has been, or can be, evolved to determine the rate on which the capitalization should be based ${ }^{44}$ or the extent to which valuations based upon the capitalization of estimated profits should be modified by the consideration of other factors.

41. Northern Pacific Ry. v. Bóyd, 228 U. S. 482, 508 (19r3).

42. Case v. Los Angeles Lumber Products Co., 308 U. S. I06, 122 (1939).

43. I Bonbright, Valuation of PropertT (1937) Chapter XII; 2 id., 88a-88I, 884-889; Dewing, Financtal Poutcy of Corporations (1934) 165-170; FinteTter, op. cit. supra note $I$ at $557-558$.

44. DewING, op. cit. supra note 43 at 169-170. 
Additional elements which may enter into the determination of goingconcern values are: (I) original cost of fixed assets, less depreciation; (2) replacement value of the property; (3) rate of obsolescence of assets due to technical developments in the industry; (4) stability and prospects of the industry; (5) strength of financial set-up and ability of the corporation to weather financial storms; and (6) efficiency and integrity of the management.

Theoretically, the sum of the market prices of the securities issued by the reorganized corporation ought to be equal to the going-concern value of the corporation. Actually, it may be more, or less-usually less, because the new management has not yet demonstrated its ability to make the estimated profits. In addition to the value of the corporation as a going concern, the following elements must be considered in the valuation of its securities: (I) maturity date of the security; (2) rate of interest or dividend, and whether fixed or contingent; (3) value and liquidity of collateral or mortgage security, if any; (4) preferences or priorities upon general distribution; (5) legal remedies for failure to pay; (6) nature of the business; (7) reputation of the management for efficiency and integrity; (8) policies of management as to payment of dividends, etc.; (9) number and dispersion of holdings of the securities; (IO) listing on an exchange or existence of over-the-counter market; and (II) extent to which market of the security is controlled or manipulated.

Valuations of businesses and of securities are troublesome. Such valuations in the present state of our knowledge cannot be mathematically exact except in unusual and simple situations. Courts recognize this fact in passing upon the fairness of plans, and do not usually seek to substitute their views of value for those of the interested parties, unless clearly erroneous. The determination of the values of the claims against and interests in a corporation, and of the values of the interests to be substituted for them in the reorganized corporation, is, at best, a rough approximation. There is a twilight or debatable zone in every situation. So long as the valuations on which the plan is based fall within this zone, it cannot be said to be unfair. In choosing the actual value to be used in the formulation of the plan, however, preference should perhaps be given to some value in the upper, rather than the lower, part of this zone; otherwise, a junior claim or interest may be unjustly eliminated. Any injustice which might otherwise result to the holders of senior claims or interests through the use of higher rather than lower valuations, may be minimized, when doubt exists, by giving them senior securities, if this may be done without creating an unwise and unwieldly corporate structure. 


\section{E. Formulation of the Plan}

The plan of reorganization is the charter which sets forth the results desired through the reorganization proceeding. It is the aim and goal of every reorganization, the success or failure of which depends upon the merits of the plan and the benefits secured through its consummation.

In practice, the first step in the preparation of a plan is an analysis of the business. ${ }^{45}$ A diagnosis should be made of the causes of its financial difficulties. The plan should aim to cure the financial and business ailments of the debtor. ${ }^{46}$ It should not merely provide immediate relief, but should be drastic enough to assure continued solvency of the enterprise even under unfavorable conditions.

In the distribution of the new securities among those having interests and equities, creditors and stockholders, so far as is practicable, should be given obligations and securities which correspond to the obligations and securities originally held by them. ${ }^{47}$ Creditors who originally bargained for mortgage or other security, should, if possible, be permitted to retain their security; creditors who bargained for a short-term period of credit should receive cash or short-term securities; creditors who invested in long-term securities should receive similar securities.

Likewise, the retention in the plan of the old relative priorities of the claims and interests having an actual present equity in the assets of the corporation, is desirable in all cases'unless it results in a capital structure which is too stratified and complex to be sound. ${ }^{48}$

The feasibility of the plan-its readjustment of the capital structure to meet the corporate needs-is, however, of paramount importance. Feasibility must not be sacrificed to maintain the old relative priorities in the new capital structure. If it is desirable to simplify the old capital structure, new securities of the same class may be given to classes of creditors having different priorities, provided that each class receives sufficient of such securities to give it the full value of its interest or equity in the assets of the debtor.

The going-concern value of the assets is a fact on which differences of opinion are bound to exist. Such value may, like any other fact to be determined in the proceedings, be the subject of a compromise by the interested parties. ${ }^{49}$ If the court believes the compromise

45. I GERDES, op. cit. supra note I, c. 3.

46. 2 id., c. 2 I.

47. See Dodd, note 8 supra at II33-II34.

48. See Warner, Some Financial and Economic Problems in Railroad Recapitalizations (I940) 7 LAW AND CONTEMP. PROB. 438, 445-449.

49. That legitimate compromises, i. e., compromises not based solely upon nuisance value, might be made was recognized in Case v. Los Angeles Iumber Products Co., 308 
reasonably fixes the disputed value, that should be given effect regardless of the objections of class minorities. The court should not, however, justify as a compromise an agreement which is intended to give to junior classes who have no equity in the assets, a participation in the distribution of obligations and securities under the plan.

A class of claims having a readily realizable liquidation value equal to the full amounts of the claims, is in a strategic position which enables the holders of such claims to insist that they receive securities having not only a going-concern value equal to their claims but also a probable market value of the same amount, because upon consummation of a plan without acceptance by it, such a class must be paid the full amount of its claims in cash. If the reorganization is not consummated, the class will be paid in full, in cash, on a liquidation of the assets.

\section{Relative Priority Theory}

The foregoing principles have not all received universal approval. Belief is widely held that interests in the reorganized corporation may be given to classes of creditors and stockholders who have no equity based on going-concern values, provided that the old relative preferences of all classes of creditors and stockholders as to claims on earnings and on dissolution are preserved. This theory is known as the "Relative Priority Theory", s0 as opposed to the "Absolute Priority Theory", discussed hereinbefore. ${ }^{51}$

But the term "Relative Priority Theory" is misleading. It does not adequately describe the theory. Both the relative and absolute priority theories call for a recognition of the relative priorities of the old classes of claims and interest in determining the value of their equities in the assets of the debtor. The absolute priority theory, however, limits participation under the plan to the values so found, while the relative priority theory permits participation by classes who no longer have an equity. The recent decisions of the United States Supreme Court in the Los Angeles Lumber $\mathrm{Co}^{52}$ and United States Realty ${ }^{53}$ cases have clearly indicated a disposition to accept the absolute priority theory rather than the relative priority theory. But the

U. S. 106, 130 (1939). Where there is an honest doubt as to valuation, and not an attempt merely to take advantage of nuisance value, this would seem to be a legitimate issue to compromise. See Dodd, note I supra at 714 .

50. The terms "Relative Priority Theory" and "Absolute Priority Theory" were first used by Bonbright and Bergerman, Two Rival Theories of Priority Rights (I928) 28 COL. L. REV. I27.

51. See p. 46 supra.

52. Case v. Los Angeles Lumber Products Co., 308 U. S. I06 (I939).

53. Securities and Exchange Commission v. United States Realty and Improvement Co., 3ro U. S. 434 (r940). 
controversy between the two schools of thought has not been completely allayed. 54

Professor E. Merrick Dodd has given us a succinct statement of the relative priority theory:

"According to that theory, a reorganization plan is fair to creditors if it preserves to them their former preferences with respect to both their rights on dissolution and their claim on earnings, so that, for example, the holders of 6 per cent. debentures, if given 6 per cent. preferred shares with a dissolution preference equal to the face amount of their claims to principal and accrued interest, would have no legal grievance even if shareholders were given new common shares without a finding that they had any equity in the enterprise." 5 s

A proponent of the theory has stated that claims or interests which have been shown by a valuation in a proceeding under Chapter $\mathrm{X}$ to have no value may nevertheless be given a share in the reorganized corporation if the former relative priorities are retained; that, if the full priority of a senior class is maintained, any junior nonentitled class may be included; that if the holders of mortgage bonds of an insolvent debtor are given new preferred stock for the full amounts of their claims, with a dividend rate equal to the old interest rate, the old stockholders may be given all the new common stock; and that the holders of mortgage bonds of an insolvent debtor may be compelled to accept preferred stock for part of their claims and common stock for the balance, while the old common stock retains the remainder of the common stock of the reorganized debtor. ${ }^{56}$

\section{Criticism of the. Theory}

The relative priority theory, as hereinbefore defined, is unsound. It brings further confusion to a situation already confused; it adds uncertainty to uncertainty. It does not solve the real problem-the valuation of interests in a corporation-but distracts attention from that problem by substituting a rule of thumb which is totally inadequate.

54. See dissenting opinions by Simons, J., in the recent cases of Whitmore Plaza Corporation y. Smith, II3 F. (2d) 210 (C. C. A. 6th, 1940) and Metropolitan Holding Co. v. Weadock, Ir3 F. (2d) 207,209 (C. C. A. 6th, 1940) in which he states: "The underlying philosophy of all of the reorganization provisions in the Bankruptcy Act, including its agricultural adjustment provisions and the railroad and corporation reorganization sections, is that a distressed debtor should have an opportunity for rehabilitation, and that there is no inequity or constitutional infirmity in providing such opportunity so long as creditors are protected in their priorities to the full fair value of their security at the time of the reorganization ...." See Swanstrom, note I supra.

55. Dodd, note I supra at 732.

56. FinLetrap, op. cit. supra note $I$ at 457-458. 
Specific objections to the relative priority theory are that it deprives creditors and stockholders of their legal and contractual rights; it fails to define the extent to which junior creditors and stockholders who have no equity may be granted interests under the plan, and provides no adequate substitute for well-recognized principles of law and equity; its apparent àvoidance of the necessity of valuing interests in the reorganized corporation is illusory; and it tends to produce an unwieldy and undesirable capital structure for the reorganized corporation.

When people extend credit to or purchase the securities of a corporation they bargain and pay for certain rights and privileges in the enforcement of their claims. Creditors who bargain for and receive a first lien on assets of the corporation as security for their claims, pay for this additional protection-they must be content with the promise of a fixed low rate of interest. Creditors agreeing to take a subordinate position in the hierarchy of claims upon distribution receive the promise of a higher fixed rate of interest. Preferred stockholders, lower still in the scale of priorities, get the possibility of an income greater than the interest promised to unsecured creditors. And, finally, common stockholders usually get the possibility of income which is limited only by the profits of the corporation, and, in addition, collectively, get control of management. The price depends upon the rights granted and the risks taken-the more valuable the rights granted and the less the risk of loss in the event of default by the debtor, the greater the price which is paid.

These bargained-for rights of prior classes are not given effect if subordinate securities are given to junior classes which have no equity in the assets of the debtor. Consider the following illustration: Mortgage bonds of $\$ 1,000,000$; no unsecured creditors; common stockholders; value of assets, $\$ 700,000$. The plan proposes to give to the bondholders $\$ 1,000,000$ of new preferred stock, with a dividend rate equal to the rate of interest on the old bonds, and to permit the old common stockholders to retain their shares.

Under our principles of law and equity the bondholders in the foregoing situation are entitled to appropriate all of the assets of the debtor to the satisfaction of their claims, since the value of such assets is less than the amount of their claims. Do they get this under the proposed plan? By hypothesis, the total value of the assets is $\$ 700,000$. No matter how interests in such assets may be divided, the total value of such interests cannot exceed $\$ 700,000$. To the extent to which an interest is given to stockholders, therefore, the value of the interest remaining for bondholders is necessarily diminished. 
The value of the interest given to stockholders is substantial. They indirectly manage and control the company. They elect the directors of the corporation, and, through such directors, control the selection and compensation of its officers and employees, and determine its business, financial and investment policies. They may cause the corporation to take unnecessary business risks in the hope that success will enhance the value of the assets of the corporation sufficiently to show substantial values for their shares of stock and substantial profits for distribution as dividends. They have every incentive to gamble, since they have everything to gain and nothing to lose. - They are gambling with the assets of the bondholders, who sustain the losses and who get only a part of the profits if the gamble succeeds. Can there be any doubt as to the value of these rights given to the stockholders?

Implicit in the foregoing discussion is the assumption that no new consideration is required under the plan from the stockholders for the retention by them of the shares of common stock. To the extent of the value of any new consideration required to be given by themwhether by payment in cash, or binding management agreement, or otherwise-stockholders having no equity may be given an interest in the assets without adversely affecting the fairness of the plan. ${ }^{57}$

If it were conceded that values may be taken away from creditors having a priority and given to creditors having a subordinate position, or taken from creditors and given to stockholders, an important question would remain: To what extent are members of the prior class to be deprived of value for the benefit of members of subordinate classes?

Under Chapter $\mathrm{X}$, it is contemplated that the disinterested trustee will propose plans, ${ }^{58}$ the Securities and Exchange Commission will report on plans referred to it, ${ }^{59}$ and the court will approve plans ${ }^{60}$-all prior to the solicitation of acceptances from creditors or stockholders. ${ }^{61}$ Even if given without solicitation, no acceptance, and no authority to accept, is valid if given before action on the plan by the trustee, the Securities and Exchange Commission and the court, unless the court has consented to such solicitation. Since such consent has been rarely, if ever, given, it is apparent that all of these agencies must pass upon the fairness of the plan before they know whether, or to what extent, holders of prior securities are willing to permit participation by junior securities which have no equity. If the only test is to be the willing(I939)

57. See Case v. Los Angeles Lumber Products Co., 308 U. S. 106, II7, 121-122

58. $\$ 169$.

59. § 172.

60. § I74.

6r. \$176. 
ness of the senior classes to make provision for such junior classes as have no equity, how is such willingness to be determined in advance of solicitation or receipt of acceptances? It is apparent that these agencies in passing upon the plan would have to speculate as to whether the holders of senior securities would accept the recognition given to the junior non-entitled classes in the plan. In any event approval by the court, prior to its acceptance by the senior security holders, of a plan giving recognition to junior interests having no equities, will unfairly coerce such senior holders into acceptance of the plan, since the alternative will be a rejection of the plan and delay in the completion of the reorganization.

The relative priority theory is sometimes justified on the ground that going-concern values cannot be determined with exactness. ${ }^{82}$ The inexactness of such valuation may be conceded, but proponents of the theory permit such valuations-inexact as they may be-to exclude classes of creditors and stockholders. They apply the theory only to permit an interest to be taken from individual creditors having a priority when two-thirds of the class agree to give such interest to a subordinate class. If the valuation is exact enough to justify the elimination of entire classes, it surely ought to be exact enough for use in preserving the interests of individual creditors under the plan.

Proponents of the relative priority theory state that dissenting minorities of classes of creditors accepting the plan should be bound by the action of the majority-as in a composition under the old Section 12 of the Bankruptcy Act. ${ }^{63}$ But such a composition required more than the mere assent of a majority of the creditors; it required that the court find that the composition was for the best interest of the creditors-that under it creditors would receive the equivalent of what they would get if the bankruptcy were continued. The relative priority theory includes no such limitation upon the power of the majority. It permits the majority to deprive the minority of part of their equity in order to grant an interest to a class which is not entitled to any interest, and it takes away the power of the court to prevent this diversion.

When Sections 77 and $77 B$ were enacted in 1933 and 1934 they were included in Chapter VIII of the Bankruptcy Act which was entitled "Provisions for the Relief of Debtors". It is argued that the intent was to benefit stockholders (who, collectively, for practical purposes, constitute the debtor) as well as creditors. ${ }^{64}$ This may be con-

62. Finletter, op. cit. supra note I at $458-459$.

63. Downtown Inv. Ass'n v. Boston Metropolitan Bldgs., 81 F. (2d) 314, 323 (C. C. A. Ist, 1936).

64. See dissenting opinion by Simons, J., in Metropolitan Holding Co. v. Weadock, I13 F. (2d) 207,209 (C. C. A. 6th, 1940). 
ceded. But it does not follow that the benefits which are given to stockholders are such as must necessarily result from depriving creditors of their full legal right of priority. Stockholders do benefit from the going-concern values which are preserved by reorganization and which are sacrificed by liquidation, but only if such going-concern values exceed the claims of creditors. In this manner, stockholders are benefited in most, although not in all, cases.

The relative priority theory does not dispense with the necessity of valuing the assets of the reorganized debtor. Advocates of the theory admit that such valuation is necessary to determine the classes entitled to participate as of right. In any event, the statute requires the court to pass upon the fairness of the plan, ${ }^{65}$ and the United States Supreme Court has held that no court may pass upon a plan unless it has full and adequate information regarding the entire situation, including the value of the assets. ${ }^{8 B}$

It has been said that shares of stock have become more and more widely distributed among the small investors of the country, and that the application of the absolute priority theory will throw the heaviest losses upon those, who, as a class, are less able to assume them than are the holders of secured bonds or other prime securities of the corporation. ${ }^{87}$ In view of the fact that the billions of dollars invested by our savings banks and life insurance companies in the highest grades of bonds are the funds of small investors, it is extremely unlikely that the foregoing statement is correct. Even if it were correct, however, the wisdom of encouraging further investment in such junior securities is very doubtful. The relative priority theory, by cutting down the participation of the secured issues in order to give an interest to junior creditors and stockholders, would discourage investment in high grade securities and encourage investment in the junior issues by persons who ought to purchase the sounder securities. By giving to prime securities the full benefit of their priorities, we enable persons who desire to minimize the possibility of loss through defaults in the payment of interest and principal, and who are willing to pay the price, to secure what they wish. Investments may be made for widows and orphans with better assurance that they will receive the bargained-for benefits.

The application of the relative priority theory will also encourage the retention, and even the extension, of the present complicated and unwieldly stratification of our corporate structures. New underlying securities will be issued to secure additional capital—old interests will

65. §221 (2).

66. National Surety Co. v. Coriell, 289 U. S. 426,436 (I933).

67. Bonbright and Bergerman, note 50 supra at $158-159$. 
be retained, stratum by stratum, regardless of whether they still have equities in the assets of the debtor. Simplification is needed-not greater complication. A plan which fails to simplify a corporate structure which is already too complex fails to accomplish one of its most important objectives.

The relative priority theory runs counter to our present conception of proper corporate practice; it permits securities to be issued which have little, if any, value. Innocent investors may be, and will be, deceived into buying such securities.

\section{Conclusion}

The foregoing discussion essays a critical analysis of some of the fundamental principles to be applied in the formulation of a plan of corporate reorganization. No attempt has been made to sustain, by copious citations of cases, the views expressed, although it is believed that such views are in accord with the law embodied in the decisions of our courts.

Space limitations have prevented consideration of a number of interesting questions, among them: the time as of which equities in the assets of the debtor must be valued; the rate of interest which should be allowed on claims during the proceeding; the amounts for which claims should be allowed on long-term bonds having either an abnormally high, or an abnormally low, interest rate; the basis for the classification of claims; and the recognition which may be given to contingent claims.

If this article succeeds in arousing new interest in the underlying concepts of reorganization it will have accomplished its purpose. 